\title{
Primary yolk sac tumour of the prostate mimicking small round blue cell tumour
}

\author{
H. Gui MD PhD, ${ }^{*}$ R.A. Kolster $\mathrm{MD} \mathrm{PhD}^{\dagger}{ }^{\dagger}$ M.B. Palmer $\mathrm{MD} \mathrm{PhD}^{\dagger}{ }^{\dagger}$ J.S. Brooks $\mathrm{MD}^{*}{ }^{*}$ M. Zhang $\mathrm{MD} \mathrm{PhD}^{*}$ \\ and M.A. Husson MD*
}

\begin{abstract}
Prostatic yolk sac tumour is a germ cell tumour with a wide range of age of occurrence, unusual anatomic locations, diverse morphologic patterns, and aggressive biologic behavior, posing challenges both to diagnosis and clinical management.

We report a rare case of primary yolk sac tumour of the prostate with extensive local and liver metastasis, the latter of which exhibited sheets of small blue cells expressing CD99 and focal sALL4 on biopsy. Positivity for CD99 and GATA3 in the initial biopsy raised the differential diagnosis of Ewing sarcoma and poorly differentiated carcinoma. The primary tumour demonstrated an admixture of solid and glandular growth patterns and occasional Schiller-Duval bodies. A panel of immunohistochemical stains showing positivity for AE1/3, sALL4, CDX2, and focal alpha-fetoprotein, and negativity for ост-4, facilitated the diagnosis.

A thorough review of the literature and our current report indicate that a large tumour load, incomplete tumour resection, limited response to preoperative neoadjuvant chemotherapy, and late stage of the disease are predictive factors for a poor clinical outcome.
\end{abstract}

Key Words Yolk sac tumours, germ cell tumours, prostate

Curr Oncol. 2019 October;26(5):e707-e711

www.current-oncology.com

\section{INTRODUCTION}

Extragonadal germ cell tumours are much less common than their gonadal counterparts, comprising $1 \%-5 \%$ of all germ cell tumours ${ }^{1}$. Extragonadal yolk sac tumours (YSTS), like other extragonadal germ cell tumours, are rare malignant neoplasms that typically arise in the sacrococcygeal, mediastinal, retroperitoneal, and head-and-neck regions ${ }^{2}$. Only 8 cases of primary prostatic ysts have been reported in the literature ${ }^{3-10}$. Because of their extreme rarity, low index of clinical suspicion, and broad spectrum of morphologic patterns, prostatic ysTs pose a diagnostic pitfall. In addition, prostatic YsTs carry a poor prognosis, even with the advent of aggressive management with combined preoperative neoadjuvant therapy and radical prostatectomy. Here, we report a case of prostatic YsT in a young adult, with a review of the literature to determine clinicopathologic features that might help to predict clinical outcomes.

\section{CASE DESCRIPTION}

A 26-year-old man with a history of urinary urgency for 6 months was treated for prostatitis. He was subsequently admitted for worsening urinary symptoms, hematochezia, and pelvic pain. Upon admission, abdominal and pelvic computed tomography and magnetic resonance imaging showed a $12.2 \times 11.0 \times 9.1 \mathrm{~cm}$ prostatic mass [Figure $1(\mathrm{~A})$ ] locally invading the rectum and bladder neck, with pelvic lymphadenopathy and hepatic metastases [Figure 1(B)].

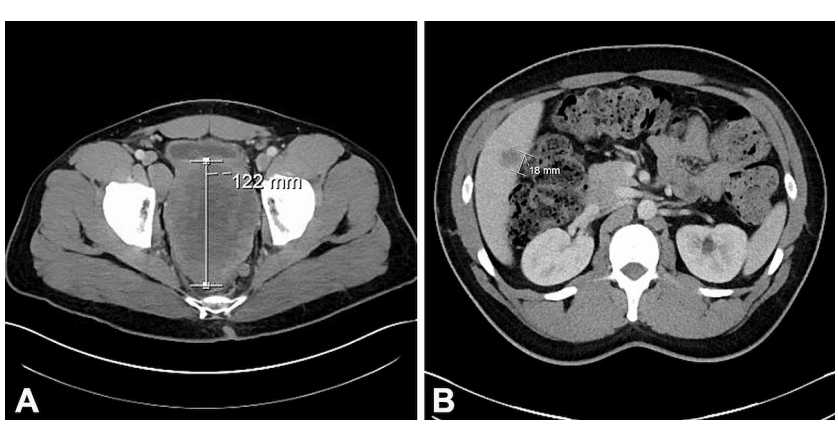

FIGURE 1 (A) Pelvic computed tomography (CT) imaging showed a $12.2 \times 11.0 \times 9.1 \mathrm{~cm}$ prostatic mass locally invading the rectum and bladder neck, with lymphadenopathy. (B) Abdominal CT imaging showed hepatic metastases measuring $1.8 \mathrm{~cm}$. 
No testicular lesion was identified by physical exam or sonography.

An initial biopsy of liver showed sheets and nests of small round blue cells with hyperchromatic nuclei and small-to-moderate amounts of eosinophilic cytoplasm [Figure 2(A)]. No glandular differentiation or other characteristic morphologies were identified. Numerous apoptotic bodies and mitotic figures were noted. Immunohistochemical studies showed that tumour cells were positive for pan-cytokeratin and CD99, partially positive for SALL4 [Figure 2(B-D)] and GATA3 (not shown), but negative for оCT-3/4, Nkx-3.1, and WT1. Expression of INI1 was retained in tumour cells.

Because the liver biopsy was inconclusive, a transrectal ultrasound-guided prostatic biopsy was subsequently performed for definitive evaluation. This second biopsy exhibited an admixture of glandular, cord-like, solid, and papillary architectures [Figure 3(A)]. Schiller-Duval bodies were occasionally present [Figure 3(B)]. Immunohistochemical stains were positive for cytokeratin AE1/3, SALL4, CDX2, and alpha-fetoprotein [AFP (focal), Figure 4(D)], and negative for оCT-3/4 [Figure 4(C)], CD30, C-kit, inhibin, human chorionic gonadotropin, cytokeratin 7 , keratin 20 , placental alkaline phosphatase, prostate-specific acid phosphatase, and Nkx-3.1. The histologic and immunohistochemical findings were diagnostic for extragonadal yolk sac tumour.

Combined neoadjuvant chemotherapy was given, and the patient initially responded well to 4 courses of etoposide, iphosphamide, and cisplatin. Serum AFP dropped from a pre-treatment baseline of $7207 \mathrm{IU} / \mathrm{mL}$ to $7 \mathrm{IU} / \mathrm{mL}$ (Figure 5). However, the tumour progressed 5 months after completion of chemotherapy, with serum AFP rebounding
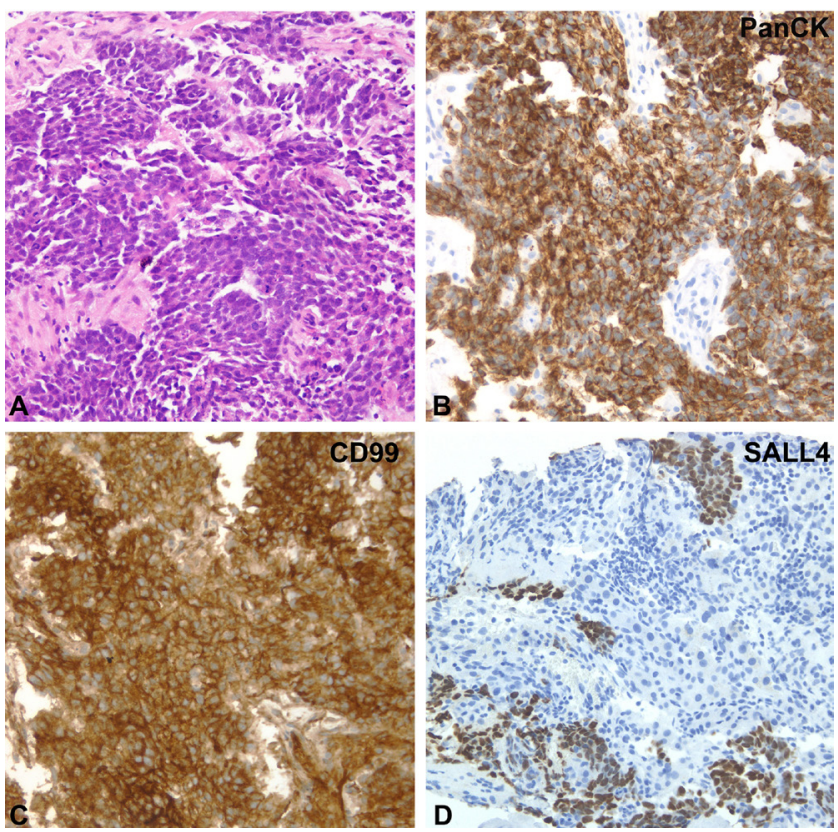

FIGURE 2 (A) The liver metastasis showed nests and sheets of small blue cells with brisk mitosis and apoptosis. The tumour cells were positive for (B) pan-cytokeratin and (C) CD99 and partially positive for (D) SALL4 (200× original magnification). to $525 \mathrm{IU} / \mathrm{mL}$. The patient received an additional 2 cycles of ifosfamide-paclitaxel, 2 cycles of high-dose carboplatinetoposide, and autologous stem-cell transplantation. Given the intractable growth of the tumour, pelvic exenteration was performed.

The pelvic exenteration specimen showed a prostate grossly obliterated by a heterogeneous, ill-defined, tanwhite to red-brown soft mass, with extensive hemorrhage

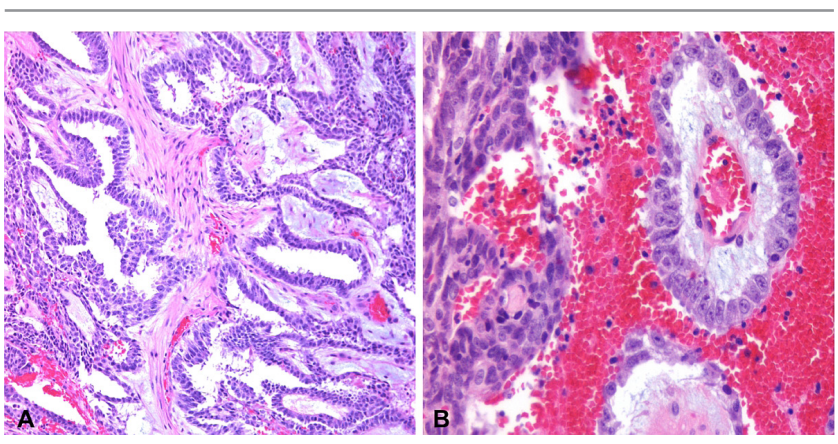

FIGURE 3 (A) The tumour showed mixed solid and glandular growth patterns (100× original magnification). (B) Schiller-Duval bodies were occasionally seen (400x original magnification).

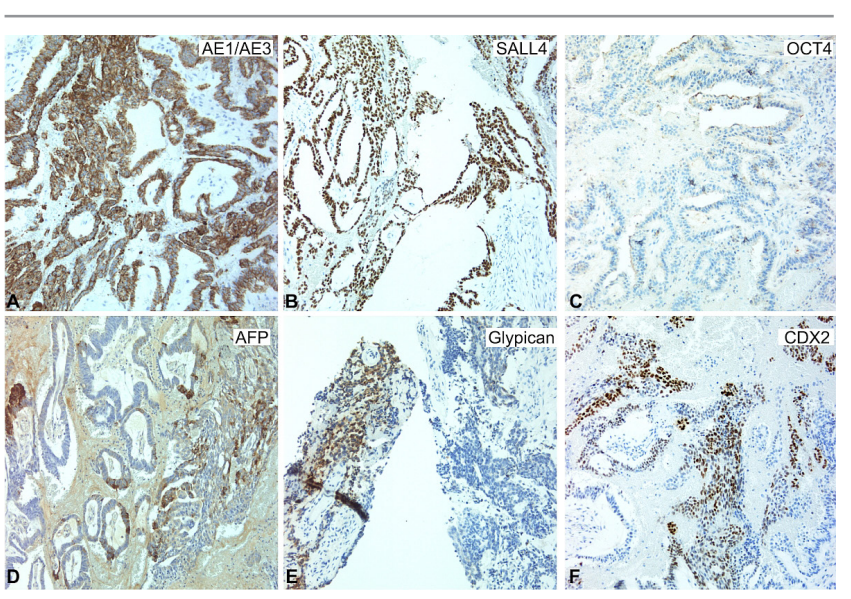

FIGURE 4 The tumour cells were positive for (A) Cytokeratin AE1/3 and (B) SALL4, but negative for (C) OCT-3/4. Focal positivity for (D) alphafetoprotein, (E) Glypican, and (F) CDX2 was observed (100× original magnification).

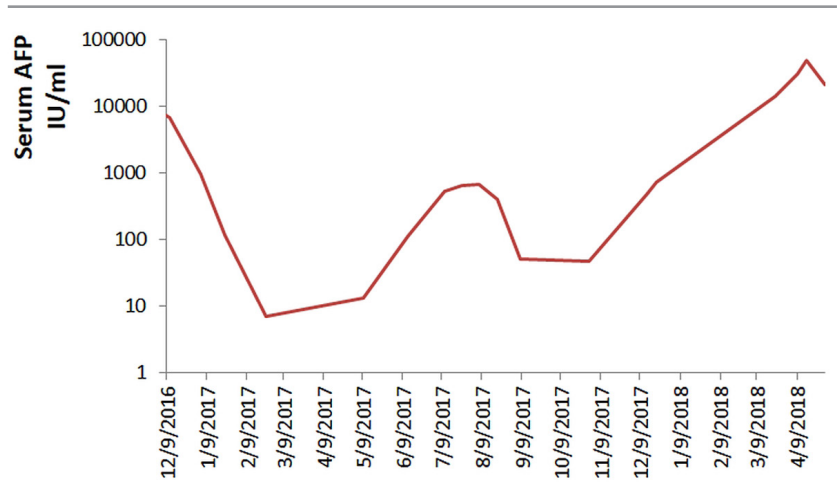

FIGURE 5 Serum alpha-fetoprotein was closely followed and showed a limited chemotherapy response by the prostatic yolk sac tumour, followed by rapid progression, with a poor outcome. 
and necrosis, measuring $5.2 \times 3.4 \times 1.5 \mathrm{~cm}$. The histology of the tumour was identical to that seen in the prostate biopsy, and the tumour cells were focally positive for AFP and Glypican [Figure 4(E)]. The tumour cells had replaced the prostate and seminal vesicles, extending to the muscular walls of rectum and bladder, as well as to the pelvic wall. Lymphovascular invasion was also present.

After the surgery, the residual tumour continued to grow within the pelvis, with extension to the perineum and direct invasion of the left symphysis pubis and pre-sacral space. A liver metastasis of $2.2 \mathrm{~cm}$ persisted. The patient developed sepsis and succumbed 18 months after the initial diagnosis of prostatic YsT.

\section{DISCUSSION}

Extragonadal YsT is a rare neoplasm that arises from the midline along the rostrocaudal axis, including brain ${ }^{11}$, head and neck ${ }^{12}$, mediastinum ${ }^{13}$, retroperitoneum, and pelvic regions ${ }^{14}$. The tumour cells likely originate from transdifferentiated cancer stem cells within somatic tissues or from primordial germ cells or primordial germ cell precursor cells arrested during their migration in early embryonic development ${ }^{15,16}$. As recognized by Teilum in $1959^{17}$, YsT is a pluripotent germ cell neoplasm that has the potential to differentiate into a tumour with a wide variety of morphologies, reminiscent of extraembryonic (yolk sac, allantois) and embryonic endoderm derivatives (thyroid, lung, intestine, liver) ${ }^{16}$. For that reason, extragonadal ysT remains a great challenge in both diagnosis and clinical management.

Here, we report a case of primary ysT of the prostate. The patient presented clinically with nonspecific urinary symptoms and was initially treated for prostatitis. Aggravation of the symptoms led to radiologic identification of a prostatic mass and probable liver metastasis. An initial liver biopsy revealed a small round blue cell tumour that could not be definitively classified at the time. Because of the unusual site in the prostate and nonspecific morphology patterns, the profile of strongly positive cytokeratin and CD99 staining raised concern for prostatic sarcoma despite partly positive staining for SALL4. The transmembrane CD99 protein is most commonly expressed in Ewing sarcoma, lymphoma, leukemia, and sex cord stromal tumours ${ }^{18}$. However, positivity for CD99 is nonspecific, and its expression has been reported in YsT $^{19}$. Conversely, SALL4 is a sensitive marker for nonteratomatous germ cell tumour and is rarely expressed in mesenchymal tumours ${ }^{20}$.

It is essential to identify YsT by both specific and nonspecific features because it carries a poor prognosis requiring aggressive clinical management ${ }^{21}$. All cases of primary YsT of the prostate (Table I), except for one with unknown histology, demonstrated at least 1 of 3 main characteristic features $^{2}$ : a reticular or microcystic pattern (4 of 8 cases), Schiller-Duval bodies ( 6 of 8 cases), and intracytoplasmic or extracellular hyaline globules (4 of 8 cases). However, initial diagnoses other than ysT were considered in 5 of 9 cases (56\%), likely because of undersampling and nonspecific patterns (solid or glandular), a wide range of ages (1-51 years), and a low index of suspicion. Schiller-Duval bodies are more common in prostatic YST than in YST arising from gonadal ${ }^{22}$ or other extragonadal $\operatorname{sites}^{14}$. However, that specific pattern might not be the predominant morphology and can present as "Schiller-Duval-like" 5 or atypical or focal Schiller-Duval bodies ${ }^{5,7}$.

In addition to morphology features, immunohistochemical studies facilitate the identification of a YsT component, which can also arise in the background of mature and immature teratoma ${ }^{8}$, carcinoma of somatic origin ${ }^{14}$, or a mixed tumour, with a component of seminoma ${ }^{7}$. A panel of cytokeratins, SALL4, AFP, and OCT- 4 is most useful for distinguishing ysT from other germ cell tumours. Embryonic-derived tumours such as embryonal carcinoma or seminoma express high levels of OCT- ${ }^{23,24}$; YST is negative for OcT-4. Yolk sac tumour, choriocarcinoma, and teratoma can be positive for cytokeratins, AFP, and Glypican, but the latter two entities are mostly negative for SALL4 and placental alkaline phosphatase. In addition, endodermal lineage markers TTF1 (lung), CDX2 (intestine), and Hep Par 1 (liver) are variably expressed in YsT and to some degree correlate with various YST morphologies ${ }^{25}$. The expression of those markers (diffuse versus focal, strong versus weak) should be appropriately interpreted to distinguish between extragonadal ysT and metastasis from lung, gastrointestinal, or hepatocellular carcinomas.

Since the introduction of cisplatin into the management of germ cell tumours in the $1970 \mathrm{~s}^{26}$ and the advent of preoperative neoadjuvant chemotherapy ${ }^{27}$, the prognosis of patients with germ cell tumours has improved. However, the clinical outcome of prostatic ysT, like extragonadal YsT from other sites, is worse than for gonadal yst (Table I). In 6 of 9 cases of prostatic ysT $(67 \%$, including the present case), the patients died within 18 months of the initial diagnosis. Of those patients, 5 received a combination of radical prostatectomy and cisplatin-based chemotherapy, with the tumour showing no or a limited response in 4 cases. The 3 remaining patients receiving cisplatin-based chemotherapy showed long-term disease-free survival (1-4 years). The determinant of the rate of response to chemotherapy is not known. Interestingly, of 3 patients who had an excellent chemotherapy response, 2 had Klinefelter syndrome, and 1, with a prior testicular seminoma, had completed post-orchiectomy chemotherapy. In addition to a limited response to preoperative neoadjuvant chemotherapy, other poor prognostic factors include a large tumour load; incomplete resection, with residual tumour; and late-stage disease, with lymph node and distant metastasis ${ }^{3-7}$.

\section{SUMMARY}

Primary YsT of the prostate is a very rare tumour that is diagnostically challenging because of its unusual anatomic location and diverse histologic patterns, especially when it presents with predominantly nonspecific solid or glandular morphologies, with sheets of small round blue cells. A high index of suspicion, clinicopathologic correlation, and appropriate immunohistochemical studies facilitate an accurate diagnosis. Appropriate clinical management includes preoperative neoadjuvant chemotherapy, radical surgery, and postoperative treatment, with subsequent close monitoring of serum AFP. 
PROSTATIC YOLK SAC TUMOUR, Gui et al.

TABLE I Clinicopathologic features of prostatic yolk sac tumour

\begin{tabular}{|c|c|c|c|c|c|c|}
\hline Reference & $\begin{array}{l}\text { Age } \\
\text { (years) }\end{array}$ & $\begin{array}{c}\text { Initial } \\
\text { diagnosis }\end{array}$ & $\begin{array}{l}\text { Tumour } \\
\text { size } \\
(\mathbf{c m})\end{array}$ & Morphology & Treatment & $\begin{array}{l}\text { Clinical } \\
\text { outcome }\end{array}$ \\
\hline Benson et al., $1978^{4}$ & 51 & $\begin{array}{c}\text { Bladder } \\
\text { carcinosarcoma }\end{array}$ & NA & $\begin{array}{l}\text { Solid, papillary and glandular, cysts, } \\
\text { Schiller-Duval bodies and } \\
\text { PAS-positive globules }\end{array}$ & $\begin{array}{l}\text { Radical } \\
\text { prostatectomy, } \\
\text { chemoradiation }\end{array}$ & $\begin{array}{c}\text { Died of } \\
\text { disease, } \\
\text { after } 10 \text { months }\end{array}$ \\
\hline Dalla Palma et al., $1988^{5}$ & 29 & $\begin{array}{c}\text { Prostatic } \\
\text { adenocarcinoma }\end{array}$ & NA & $\begin{array}{l}\text { Solid nests and channels in } \\
\text { reticular pattern, pseudopapillary } \\
\text { and polyvesicular patterns, } \\
\text { "Schiller-Duval-like" diastase-resistant } \\
\text { PAS-positive and AFP-positive } \\
\text { hyaline bodies }\end{array}$ & $\begin{array}{l}\text { Radical } \\
\text { prostatectomy, } \\
\text { chemotherapy }\end{array}$ & $\begin{array}{l}\text { Died of } \\
\text { disease, } \\
\text { after } 10 \text { months }\end{array}$ \\
\hline Schriber et al., $1990^{9}$ & 40 & Prostate tumour & 6 & $\begin{array}{l}\text { Microcystic, papillary and solid pattern, } \\
\text { Schiller-Duval bodies, } \\
\text { focal AFP positivity }\end{array}$ & $\begin{array}{l}\text { Chemotherapy, } \\
\text { radical } \\
\text { cystoprostatectomy, } \\
\text { removal of rectum }\end{array}$ & $\begin{array}{l}\text { Died of } \\
\text { complications, } \\
\text { after } 4 \text { months }\end{array}$ \\
\hline Tay et al., $1995^{10}$ & 43 & Yolk sac tumour & 10 & $\begin{array}{l}\text { Pleomorphic, atypical Schiller-Duval } \\
\text { bodies, PAS-positive hyaline globules, } \\
\text { cytokeratin-positive, focal AFP positivity }\end{array}$ & $\begin{array}{l}\text { Cisplatin-based } \\
\text { chemotherapy, } \\
\text { radical } \\
\text { cystoprostatectomy }\end{array}$ & $\begin{array}{l}\text { No evidence } \\
\text { of disease, } \\
\text { after } 20 \text { months }\end{array}$ \\
\hline Namiki et al., $1999^{8}$ & 33 & $\begin{array}{l}\text { Yolk sac tumour, } \\
\text { teratoma }\end{array}$ & 6.5 & Solid and microcystic & $\begin{array}{l}\text { Cisplatin-based } \\
\text { chemotherapy, } \\
\text { radiation }\end{array}$ & $\begin{array}{l}\text { No evidence } \\
\text { of disease, } \\
\text { after } 4 \text { years }\end{array}$ \\
\hline Han et al., $2003^{7}$ & 24 & $\begin{array}{l}\text { Primary } \\
\text { prostatic tumour } \\
\text { and seminoma }\end{array}$ & 6 & $\begin{array}{l}\text { Papillary and glandular in fibrous } \\
\text { or myxoid stroma, most AFP-positive, } \\
\text { focal Schiller-Duval bodies, } \\
\text { many PAS-positive hyaline bodies, } \\
\text { focal seminoma }\end{array}$ & $\begin{array}{l}\text { Total } \\
\text { cystoprostatectomy, } \\
\text { cisplatin-based } \\
\text { chemotherapy }\end{array}$ & $\begin{array}{c}\text { Died of } \\
\text { disease, } \\
\text { after } 8 \text { months }\end{array}$ \\
\hline Furr et al., $2015^{6}$ & 36 & $\begin{array}{l}\text { History of } \\
\text { testicular } \\
\text { seminoma }\end{array}$ & NA & $\begin{array}{l}\text { Histology not provided, } \\
\text { tumour involving prostatic urethra }\end{array}$ & $\begin{array}{l}\text { Cisplatin-based } \\
\text { chemotherapy, } \\
\text { prostatectomy }\end{array}$ & $\begin{array}{l}\text { No evidence } \\
\text { of disease, } \\
\text { after } 12 \text { months }\end{array}$ \\
\hline Abdelhalim et al., $2016^{3}$ & 1.1 & $\begin{array}{c}\text { Primary } \\
\text { yolk sac tumour }\end{array}$ & 5.8 & $\begin{array}{l}\text { Solid sheets, microcystic and } \\
\text { glandular structures } \\
\text { with myxoid stroma, }\end{array}$ & $\begin{array}{l}\text { Radical } \\
\text { prostatectomy, } \\
\text { cisplatin-based } \\
\text { chemotherapy }\end{array}$ & $\begin{array}{c}\text { Died of } \\
\text { disease, } \\
\text { after } 17 \text { months }\end{array}$ \\
\hline Present study & 26 & $\begin{array}{l}\text { Small round } \\
\text { blue cell tumour }\end{array}$ & 12.2 & $\begin{array}{l}\text { Glandular, cord-like, solid and } \\
\text { papillary architectures, } \\
\text { occasional Schiller-Duval bodies }\end{array}$ & $\begin{array}{l}\text { Chemotherapy, } \\
\text { radical } \\
\text { cystoprostatectomy, } \\
\text { removal of rectum }\end{array}$ & $\begin{array}{c}\text { Died of } \\
\text { disease, } \\
\text { after } 18 \text { months }\end{array}$ \\
\hline
\end{tabular}

$\mathrm{NA}=$ not available; $\mathrm{PAS}=$ periodic acid-Schiff; AFP = alpha-fetoprotein.

\section{ACKNOWLEDGMENTS}

This work was presented at the 2017 annual meeting of the American Society for Clinical Pathology; Chicago, IL, U.S.A.; 7 September 2017.

\section{CONFLICT OF INTEREST DISCLOSURES}

We have read and understood Current Oncology's policy on disclosing conflicts of interest, and we declare that we have none.

\section{AUTHOR AFFILIATIONS}

*Department of Pathology and Laboratory Medicine, Pennsylvania Hospital of the University of Pennsylvania Health System, and ${ }^{\dagger}$ Department of Pathology and Laboratory Medicine, Hospital of the University of Pennsylvania, Philadelphia, PA, U.S.A.

\section{REFERENCES}

1. McKenneyJK, Heerema-McKenney A, Rouse RV. Extragonadal germ cell tumors: a review with emphasis on pathologic features, clinical prognostic variables, and differential diagnostic considerations. Adv Anat Pathol 2007;14:69-92.

2. Young RH. The yolk sac tumor: reflections on a remarkable neoplasm and two of the many intrigued by it-Gunnar Teilum and Aleksander Talerman-and the bond it formed between them. Int J Surg Pathol 2014;22:677-87.

3. Abdelhalim A, El-Hawary AK, Helmy TE, et al. Primary yolk sac tumor of the prostate in a child: case report. Clin Genitourin Cancer 2016;14:e535-7.

4. Benson RC, Jr., Segura JW, Carney JA. Primary yolk-sac (endodermal sinus) tumor of the prostate. Cancer 1978;41:1395-8. 
5. Dalla Palma P, Dante S, Guazzieri S, Sperandio P. Primary endodermal sinus tumor of the prostate: report of a case. Prostate 1988;12:255-61.

6. Furr JR, Mellis AM, Slobodov G. Primary yolk sac tumor of the prostate: a case report and review of the literature. Urol Int 2015;95:240-2.

7. Han G, Miura K, Takayama T, Tsutsui Y. Primary prostatic endodermal sinus tumor (yolk sac tumor) combined with a small focal seminoma. Am J Surg Pathol 2003;27:554-9.

8. Namiki K, Tsuchiya A, Noda K, et al. Extragonadal germ cell tumor of the prostate associated with Klinefelter's syndrome. Int J Urol 1999;6:158-61.

9. Schriber J, Flax S, Trudeau M, et al. Primary yolk sac (endodermal sinus) tumor of the prostate: case report and review of the literature. Prostate 1990;17:137-43.

10. Tay HP, Bidair M, Shabaik A, Gilbaugh JH 3rd, Schmidt JD. Primary yolk sac tumor of the prostate in a patient with Klinefelter's syndrome. J Urol 1995;153:1066-9.

11. Fujimaki T. Central nervous system germ cell tumors: classification, clinical features, and treatment with a historical overview. J Child Neurol 2009;24:1439-45.

12. Devaney KO, Ferlito A. Yolk sac tumors (endodermal sinus tumors) of the extracranial head and neck regions. Ann Otol Rhinol Laryngol 1997;106:254-60.

13. Moran CA, Suster S, Koss MN. Primary germ cell tumors of the mediastinum: III. Yolk sac tumor, embryonal carcinoma, choriocarcinoma, and combined nonteratomatous germ cell tumors of the mediastinum - a clinicopathologic and immunohistochemical study of 64 cases. Cancer 1997;80:699-707.

14. Ravishankar S, Malpica A, Ramalingam P, Euscher ED. Yolk sac tumor in extragonadal pelvic sites: still a diagnostic challenge. Am J Surg Pathol 2017;41:1-11.

15. De Felici M. Origin, migration, and proliferation of human primordial germ cells. Oogenesis 2013;:19-37.

16. Nogales FF, Preda O, Nicolae A. Yolk sac tumours revisited. A review of their many faces and names. Histopathology 2012;60:1023-33.
17. Teilum G. Endodermal sinus tumors of the ovary and testis. Comparative morphogenesis of the so-called mesoephroma ovarii (Schiller) and extraembryonic (yolk sac-allantoic) structures of the rat's placenta. Cancer 1959;12:1092-105.

18. Pasello M, Manara MC, Scotlandi K. CD99 at the crossroads of physiology and pathology.JCell Commun Signal 2018;12:55-68.

19. Gordon MD, Corless C, Renshaw AA, Beckstead J. CD99, keratin, and vimentin staining of sex cord-stromal tumors, normal ovary, and testis. Mod Pathol 1998;11:769-73.

20. Miettinen M, WangZ, McCuePA, etal. SALL4 expression in germ cell and non-germ cell tumors: a systematic immunohistochemical study of 3215 cases. Am J Surg Pathol 2014;38:410-20.

21. International Germ Cell Consensus Classification: a prognostic factor-based staging system for metastatic germ cell cancers. International Germ Cell Cancer Collaborative Group. J Clin Oncol 1997;15:594-603.

22. Langley FA, Govan AD, Anderson MC, Gowing NF, Woodcock AS, Harilal KR. Yolk sac and allied tumours of the ovary. Histopathology 1981;5:389-401.

23. Hattab EM, Tu PH, Wilson JD, Cheng L. ост4 immunohistochemistry is superior to placental alkaline phosphatase (PLAP) in the diagnosis of central nervous system germinoma. Am J Surg Pathol 2005;29:368-71.

24. Jones TD, Ulbright TM, Eble JN, Baldridge LA, Cheng L. ост4 staining in testicular tumors: a sensitive and specific marker for seminoma and embryonal carcinoma. Am J Surg Pathol 2004;28:935-40.

25. Shojaei H, Hong H, Redline RW. High-level expression of divergent endodermal lineage markers in gonadal and extragonadal yolk sac tumors. Mod Pathol 2016;29:1278-88.

26. Einhorn LH, Donohue J. Cis-diamminedichloroplatinum, vinblastine, and bleomycin combination chemotherapy in disseminated testicular cancer. Ann Intern Med 1977;87:293-8.

27. Rudaitis V, Mickys U, Katinaite J, Dulko J. Successful treatment of advanced stage yolk sac tumour of extragonadal origin: a case report and review of literature. Acta Med Litu 2016;23:110-16. 